\title{
Using Some Technical Operations For Improvement of Quality of King Ruby Grapes
}

\author{
B.E. Belal, M.A. El-kenawy and M.A.M. Abada \\ Viticulture Department, Horticulture Research Institute, \\ Agricultural Research Centre, Cairo, Egypt.
}

\begin{abstract}
7 HIS investigation was conducted for two successive seasons (2014 \& 2015) on King Ruby cultivar in a private vineyard at Eldeer village, Aga Center, Dakahlia Governorate, Egypt. The chosen vines were fifteen years old, planted in a clay soil under surface irrigation system, spaced at $2 \times 3 \mathrm{~m}$ using spur pruning under bilateral cardon trellis method with supporting by double $\mathrm{T}$ system. This study was carried out to disclose the effect of manual thinning either removing one quarter of the clusters or removing the terminal quarter of the cluster solely after fruit set or in combination with leaf basal removal after fruit set or with trunk girdling at veraison stage.
\end{abstract}

The results showed that all conducted treatments were effective in improvement the quality of King Ruby grapes as compared with control. Although the vines for which the terminal quarter of the clusters is removed alone or in combination with leaf basal removal or girdling or with leaf basal removal and girdling decreased cluster weight as compared with the vines for which one quarter of the clusters is removed alone or in combination with leaf basal removal or girdling or with leaf basal removal and girdling but gave the highest yield and improved physical and chemical properties of berries such as berry weight, volume, length and width as well as SSC, SSC/acid ratio, total anthocyanin, total sugar, decreased total acidity in berry juice and decreased the percentage of shot berries /cluster.

The application of removing the terminal quarter of the clusters after fruit set in combination with leaf basal removal after fruit set and girdling at verasion stage gave the best values in yield and improved physical and chemical characteristics of berries.

Keywords: Grape, King Ruby, Manual thinning, Leaf basal removal and Girdling.

Grape (Vitis vinifera L) is suggested to be one of the most important fruits for local consumption and export. In Egypt, grape is considered the second major fruit crop after citrus. The total cultivated area of grape in Egypt reached about 192873 feddans among them about 164310 feddans fruitful with a total production about 1434666 tons according to the statistics of the Ministry of Agriculture (2013). Ruby Seedless cultivar become one of the most important table grapes both in local and export markets. Small berry size and little coloration were produced during the last several years which affect the fruit 
quality. The grape grower donated all cultural practices a great attention to improve the yield and berry quality.

Good quality in table grape represents a combination of medium size cluster of uniform large perfect berries with colour, pleasant flavour and texture. There are many factors of grape growing enter into the production of quality. Some of these factors have direct effect on the vine and its fruits such as cluster thinning, summer pruning and girdling treatments Winkler et al. (1974) and Kamiloğlu (2011).

Manual thinning of berries to increase berry weight, size and improve the quality of the grapes as mentioned by Omran et al. (2004), Abd El-Wahab (2006), Aisha et al. (2006), Abd El-Fattah et al. (2009), El-Hussanny (2009) and Abd El-Razek et al. (2010). Also, Kamiloğlu (2011) reported that juice quality (TSS, TSS /acidity and Total anthocyanin) increased as compared to the control by the cluster thinning.

Cluster thinning is a method of the yield regulation, with the removal of part of cluster, consequently, the yield per leaf area will be lower and the grape and wine quality will be improved Fazekas et al. (2012).

Summer pruning consists of the removal of any vegetative tissues during the growing seasons including shoot thinning, cluster tendril if present, leaf removal, tipping, pinching, and topping of shoot. This practice is very important for vine life, training, vigor, quality and productivity Abd El-Ghany (2005).

Leaf removal is important in canopy management. Sunlight-exposed fruits contain more sugar and less acid than non-exposed fruits Koblet (1984). Removing basal leaves slightly changed temperature, atmospheric humidity, wind speed, and leaf wetness around grape clusters English et al. (1990).

Many investigators explained the effect of leaf removal on the total soluble solids, anthocyanin and acidity of grape berries. They found that sunlightexposed fruits are generally greater in total soluble solids, anthocyanin and lower in titratable acidity, compared to non exposed fruits or canopy shaded Ferree et al. (2004), Kliewer \& Dokoozlian (2005), Santesteban \& Royo (2006) and Prajitna et al. (2007).

Reynolds et al. (2006) mentioned that leaf basal removal increased color intensity and anthocyanin in berries. Also, Abd El-Razek et al. (2010) found that defoliation play an essential role in improving fruit quality of 'Crimson Seedless' Grapes.

Girdling which consists of removing a small section of phloem (about $4 \mathrm{~mm}$ in width) from around the trunk to produce large berries of grapes intended for table use or to enhance fruit maturity by enhancing coloration or accumulation of

Egypt. J. Hort. Vol. 43, No.1 (2016) 
sugar (Williams \& Ayars (2005) and Abu-Zahra \& Salameh (2012). Also, girdling grapevine at veraison stage increases accumulation of carbohydrates in the parts above girdle and resulted in enhancing the development of colour and SSC \% and therefore hasten maturity (Fawzi \& Eman (2003) and Omar \& Girgis (2005).

Rather et al. (2011) suggests that girdling and growth regulators application are a desirable practice to enhance berry ripening and fruit quality in grape cv. Perlette.

The target of the present study is to disclose the effect of clusters thinning solely or in combination with leaf basal removal or girdling as possible means for improving cluster and berry quality of King Ruby grapes.

\section{Materials and Methods}

This investigation was carried out during two successive seasons (2014 \& 2015) in a private vineyard at El-deer village, Aga Center, Dakahlia Governorate, Egypt. The experiment was conducted on 15-year-old King Ruby grapevines cultivar. Vines cultivated at $2 \mathrm{~m}$ within- rows and $3 \mathrm{~m}$ between-rows. The vines are grown in a clay soil under surface irrigation system under bilateral cardon trellis method with supporting by double (T) system. During January of each experimental season, the tested vines were spur- pruned by leaving 6 spurs with 2 eyes on each cardon. The total load was 48 buds. Eighty one vines, uniform in vigor as possible, were chosen for this study, all vines received the cultural managements, such as fertilization, irrigation, disease and pest control that commonly performed in that district. When cluster development reached (7$10 \mathrm{~cm}$ in length) crop load was adjusted to 28 clusters per vine. The experiment consists of nine treatments arranged in a complete randomize block design, each treatment include 3 replicates, each contain 3 vines.

The treatments were as the following:

T1 - Control (Un-thinned vine).

T2 - Removing one quarter of the clusters number.

T3 - Removing one quarter of the clusters number + Leaf basal removal.

T4 - Removing one quarter of the clusters number + Girdling.

T5 - Removing one quarter of the clusters number + Leaf basal removal + Girdling.

T6 - Removing the terminal quarter of the cluster.

T7 - Removing the terminal quarter of the cluster + Leaf basal removal.

T8 - Removing the terminal quarter of the cluster + Girdling.

T9 - Removing the terminal quarter of the cluster + Leaf basal removal + Girdling.

Cluster thinning treatments was carried out after fruit set as follows :

- Control (Un-thinned vine) number of clusters fixed to 28 clusters per vine. 
- Removing one quarter of the clusters number, thus retained 21clusters per vine.

- Removing the terminal quarter of the cluster thus retained 28 clusters per vine.

Leaf basal removal was done after fruit set, all subjacent leaves from the cluster to the basal of shoot were removal except the adjacent leaf of the cluster.

Girdling was carried out at veraison stage by removing a narrow ring of the bark $(3 \mathrm{~mm})$ entirely around the trunk.

\section{Measurements}

Yield

At harvesting time when SSC \% in berry reached about 16-17\% in control Hamza (2013), six clusters /vine were weighted and the average cluster weight was multiplied by number of clusters/vine and hence average yield/vine was calculated.

\section{Physical properties}

A sample of 6 clusters /vine was taken for determining: Average cluster weight $(\mathrm{g})$, Average cluster length and width $(\mathrm{cm})$, Average of berry weight $(\mathrm{g})$, berry volume $\left(\mathrm{cm}^{3}\right)$ and berry length and width $(\mathrm{cm})$. While the percentage of shot berries of cluster was calculated by dividing weight of shot berries by weight of total berries per cluster.

\section{Chemical properties}

- Soluble solids content (SSC \%) was determined by using a hand refractometer.

- Total acidity percentage was determined according to A.O.A.C. (1980).

- SSC/acid ratio was calculated by dividing the percentage of SSC by total acidity.

- Total anthocyanin of the berry skin ( $\mathrm{mg} / 100 \mathrm{~g}$ fresh weight) were calculated accordin to Husia et al. (1965).

- Total sugars (\%) were determined according to Sadasivam and Manickam (1996).

- Total carbohydrates in the canes $(\%)$ were determined at winter pruning according to Hedge and Hofreiter (1962).

\section{Statistical analysis}

The complete randomized block design was adopted for the experiment. The statistical analysis of the present data was carried out according to Snedecor and Chocran (1980). Averages were compared using the new L.S.D. values at 5\% level. 


\section{Results and Discussion}

\section{Yield and physical properties of cluster}

Data in Table 1 showed that the vines for which the terminal quarter of the cluster was removed alone (T6) or in combination with leaf basal removal (T7) or girdling (T8) and leaf basal removal in combination with girdling (T9) significantly increased yield/vine than the vines for which one quarter of the clusters number was removed alone (T2) or in combination with leaf basal removal (T3) or girdling (T4) and leaf basal removal in combination with girdling (T5). In this respect, girdling treatment (T8) and leaf basal removal in combination with girdling treatment (T9) under removing the terminal quarter of the cluster gave the highest values when compared with the other treatments during the two seasons of study.

These results are in agreement with those obtained by Omran et al. (2004) who found that one quarter cluster removal (one quarter apical main stem of cluster was cut) increased yield/vine as compared with control. Abd El-Wahab (2006) reported that girdling trunk at version stage improved yield/vine. ElHussanny (2009) found that removing one third of flower cluster and girdling trunk of Roomy Red increased yield /vine

Also, data revealed that the average cluster weight was significantly higher from the vines for which one quarter of the clusters number was removed alone (T2) or in combination with leaf basal removal (T3) or girdling (T4) and leaf basal removal in combination with girdling (T5) than those obtained from the vines for which the terminal quarter of the cluster was removed alone (T6) or in combination with leaf basal removal (T7) or girdling (T8) or leaf basal removal in combination girdling (T9) and control (T1). In this respect, girdling treatment (T4) alone or in combination with leaf removal (T5) under removing one the quarter of the clusters number produced the highest values of cluster weight compared with other treatments in both season of study.

These results are in agreement with those reported by many investigators such as Aisha et al. (2006) who found that removing one quarter of the clusters number at berry set significantly increased cluster weight compared with control. Also, Abu-Zahra (2010) found that girdling the canes at berry set significantly increased cluster weight. In addition, Abd El-Razek et al. (2010) found that leaf basal removal and leaf basal removal in combination with fruiting thinning improved cluster weight.

With respect to cluster length and width the data showed that girdling treatment (T4) alone or in combination with leaf basal removal (T5) under removing one the quarter of the clusters number gave the highest values of cluster length while girdling treatment (T8) alone or in combination with leaf basal removal (T9) under removing the terminal quarter of the cluster gave the highest values of cluster width. 
B.E. BELAL et al.

\begin{tabular}{|c|c|c|c|c|c|c|c|c|c|c|c|}
\hline \multirow{2}{*}{ 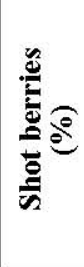 } & $\stackrel{n}{\pi}$ & $\stackrel{2}{9}$ & $\stackrel{\infty}{\infty}$ & $\frac{0}{a}$ & $\mid \begin{array}{c}m \\
\infty\end{array}$ & $\underset{\infty}{\mathbb{N}}$ & $\begin{array}{l}\infty \\
\infty \\
\text { in }\end{array}$ & $\frac{9}{6}$ & $\ddot{m}$ & $\stackrel{\infty}{\stackrel{\infty}{c}}$ & $\mid \begin{array}{l}\hat{\imath} \\
\hat{o}\end{array}$ \\
\hline & $\stackrel{ \pm}{\stackrel{\sim}{*}}$ & $\stackrel{\infty}{\stackrel{m}{\Xi}}$ & 웅 & $\begin{array}{l}\infty \\
\infty \\
\infty\end{array}$ & $\left|\begin{array}{c}0 \\
\hdashline \\
0\end{array}\right|$ & $\stackrel{\circ}{\circ}$ & $\underset{0}{\sigma}$ & $\begin{array}{l}8 \\
0 \\
0\end{array}$ & $\frac{9}{6}$ & $\begin{array}{l}m \\
\dot{n}\end{array}$ & $\stackrel{\infty}{0}_{0}^{\infty}$ \\
\hline \multirow{2}{*}{ 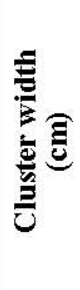 } & 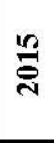 & $\begin{array}{l}m \\
\text { i }\end{array}$ & $\stackrel{m}{m}$ & $\begin{array}{l}8 \\
\text { m }\end{array}$ & $\begin{array}{l}8 \\
8 \\
2\end{array}$ & $\begin{array}{l}8 \\
\dot{0}\end{array}$ & $\stackrel{\bullet}{\bullet}$ & $\stackrel{m}{ \pm}$ & $\stackrel{\stackrel{\circ}{\circ}}{\stackrel{\square}{ \pm}}$ & $\begin{array}{l}8 \\
\stackrel{8}{2}\end{array}$ & $\stackrel{\circ}{\stackrel{0}{-1}}$ \\
\hline & $\stackrel{ \pm}{\stackrel{\sim}{*}}$ & 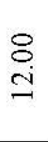 & $\stackrel{8}{8}$ & $\begin{array}{l}\stackrel{0}{0} \\
\stackrel{i}{-}\end{array}$ & $\left|\begin{array}{l}0 \\
0 \\
0 \\
\hdashline \\
\hdashline\end{array}\right|$ & $\stackrel{m}{m}$ & $\stackrel{m}{\stackrel{m}{I}}$ & $\stackrel{8}{\stackrel{8}{+}}$ & $\begin{array}{l}\stackrel{\circ}{\circ} \\
\stackrel{-}{-}\end{array}$ & 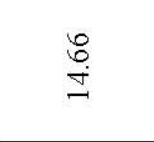 & ?ִ \\
\hline \multirow{2}{*}{ 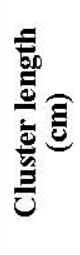 } & 水 & \begin{tabular}{l}
8 \\
0 \\
\hdashline \\
\hdashline
\end{tabular} & $\stackrel{m}{r}$ & 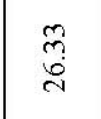 & $\begin{array}{l}8 \\
8 \\
\infty \\
\\
\end{array}$ & $\begin{array}{l}8 \\
8 \\
\text { ¿े }\end{array}$ & $\stackrel{m}{m}$ & $\begin{array}{l}8 \\
8 \\
2\end{array}$ & $\stackrel{8}{\circ}$ & $\stackrel{m}{m}$ & 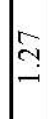 \\
\hline & 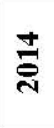 & $\begin{array}{l}m \\
m \\
\sim\end{array}$ & $\frac{8}{8}$ & $\begin{array}{l}8 \\
\stackrel{0}{0} \\
\stackrel{0}{0}\end{array}$ & $\begin{array}{l}m \\
m \\
\sim\end{array}$ & $\begin{array}{l}8 \\
\infty \\
\infty \\
\stackrel{N}{ }\end{array}$ & $\begin{array}{l}8 \\
\stackrel{8}{2}\end{array}$ & $\stackrel{m}{m}$ & $\stackrel{m}{2}$ & $\begin{array}{l}8 \\
8 \\
9\end{array}$ & $\stackrel{n}{-}$ \\
\hline \multirow{2}{*}{ 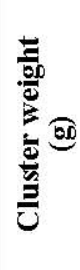 } & 水 & $\begin{array}{l}\text { m} \\
\infty \\
\stackrel{0}{\circ}\end{array}$ & $\begin{array}{l}\mathscr{8} \\
\dot{0} \\
\tilde{n}\end{array}$ & $\begin{array}{l}\stackrel{8}{0} \\
\text { 范 }\end{array}$ & 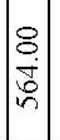 & 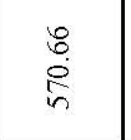 & $\begin{array}{l}8 \\
\stackrel{8}{8} \\
\stackrel{\infty}{+}\end{array}$ & $\begin{array}{l}8 \\
\infty \\
\stackrel{\infty}{\sigma}\end{array}$ & $\begin{array}{l}\stackrel{8}{\circ} \\
\stackrel{+}{\circ}\end{array}$ & $\begin{array}{l}m \\
\ddot{n} \\
\stackrel{8}{n}\end{array}$ & 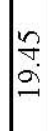 \\
\hline & 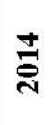 & $\begin{array}{l}\stackrel{8}{0} \\
\text { రे } \\
\stackrel{\sigma}{\sigma}\end{array}$ & $\begin{array}{l}8 \\
\stackrel{8}{5} \\
\text { in }\end{array}$ & $\begin{array}{l}8 \\
\stackrel{8}{0} \\
\text { in }\end{array}$ & $\left|\begin{array}{c}8 \\
0 \\
i \\
n \\
n\end{array}\right|$ & $\begin{array}{l}m \\
\ddot{b} \\
\stackrel{n}{n}\end{array}$ & $\begin{array}{l}80 \\
\stackrel{B}{5} \\
\frac{5}{7}\end{array}$ & 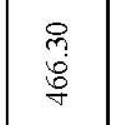 & $\begin{array}{l}8 \\
\infty \\
\infty \\
\stackrel{\infty}{+}\end{array}$ & $\begin{array}{l}8 \\
\text { ì } \\
\text { gे }\end{array}$ & $\underset{\Xi}{\beth}$ \\
\hline \multirow{2}{*}{ 홀 } & 突 & $\vec{\exists}$ & 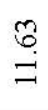 & $\stackrel{n}{=}$ & 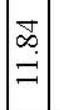 & $\stackrel{\infty}{=}$ & $\begin{array}{l}\text { J } \\
\stackrel{\text { r }}{二}\end{array}$ & 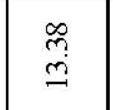 & $\begin{array}{l}\mathscr{\infty} \\
m \\
=\end{array}$ & $\stackrel{n}{\beth}$ & $\frac{0}{0}$ \\
\hline & $\stackrel{ \pm}{\vec{N}}$ & $\begin{array}{l}\mathscr{\sigma} \\
\sim \\
\sim\end{array}$ & $\stackrel{\text { f }}{\text { 二 }}$ & $\begin{array}{l}\text { m. } \\
=\end{array}$ & \begin{tabular}{l}
8 \\
\hdashline \\
$=$
\end{tabular} & $\stackrel{\infty}{=}$ & rે & $\begin{array}{l}8 \\
\stackrel{8}{-} \\
9\end{array}$ & $\begin{array}{l}\stackrel{8}{0} \\
\stackrel{-}{-}\end{array}$ & $\stackrel{\infty}{\stackrel{\infty}{\sim}}$ & के \\
\hline \multirow{3}{*}{ 慈 } & \multirow{3}{*}{ 尝 } & \multirow{2}{*}{$\begin{array}{l}\text { 옹 } \\
\text { 롱 }\end{array}$} & 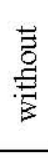 & 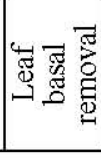 & . & 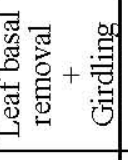 & 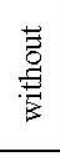 & 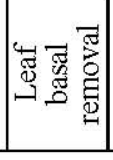 & 急 & 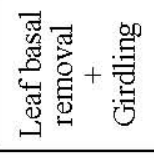 & $\begin{array}{l}0 \\
\text { in } \\
\vdots \\
\pi\end{array}$ \\
\hline & & & \multicolumn{4}{|c|}{ 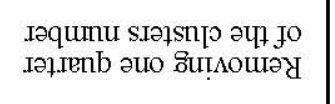 } & \multicolumn{4}{|c|}{ 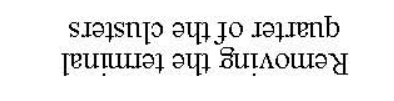 } & $\theta$ \\
\hline & & $\mapsto$ & 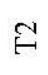 & $\hat{H}$ & 可 & 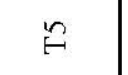 & $F$ & $E$ & $\stackrel{\infty}{\infty}$ & $\stackrel{\circ}{\circ}$ & \\
\hline
\end{tabular}

Egypt. J. Hort. Vol. 43, No.1 (2016) 
The obtained data are in accordance with those Omran et al. (2004), Abd ElWahab (2006) and Abd El-Razek et al. (2010). They found that cluster thinning, girdling and leaf basal removal increased cluster width.

Concerning the percentage of shot berries /cluster, it was found that the vines for which the terminal quarter of the cluster was removed alone or in combination with leaf basal removal or girdling and leaf basal removal in combination with girdling (T6, T7, T8, and T9) significantly decrease percentage of shot berries/cluster than the vines for which one quarter of the clusters number was removed alone or in combination with leaf basal removal or girdling or leaf basal removal in combination with girdling and control (T2, T3, T4, T5 and T1). In this respect, girdling treatment (T8) and leaf basal removal in combination with girdling treatment (T9) under removing the terminal quarter of the cluster gave the lowest values when compared with other treatments during the two seasons of study.

These results are in agreement with those obtained by Aisha et al. (2006) who found that cluster thinning at berry set decreased the percentage of shot berries/ cluster of King Ruby grapevines as compared with control.

\section{Physical properties of berries}

Data in (Table 2) indicated that all thinning treatments used either removing one quarter of the clusters number or removing the terminal quarter of the cluster alone or in combination with leaf basal removal or girdling and leaf basal removal in combination with girdling significantly increased 100 berry weight and 100 berry volume as well as enhancing berry length and width as compared with control. Vines were removing the terminal quarter of the cluster alone (T6) or in combination with leaf basal removal (T7) or girdling (T8) and leaf basal removal in combination with girdling (T9) recorded the highest values as compared with other treatments, where girdling treatment (T8) and leaf basal removal in combination with girdling treatment (T9) under removing the terminal quarter of the cluster gave the best results in this respect in both seasons of study.

These results are in harmony with those many investigators such as Omran et al. (2004) and Abd El-Fattah et al. (2009) who found that removing 25\% apical portion cluster significantly increased berry weight, volume, length and diameter.

Also, Abd El-Razek et al. (2010) reported that leaf basal removal alone and leaf basal removal in combination with fruit thinning treatments producing the heaviest berry weight, the largest volume, improved berry length and width as compared with control.

In addition, Abd El-Wahab (2006), Abu-Zahra (2010) and Abu-Zahra and Salmeh (2012) they mentioned that girdling the canes or trunk recorded the highest values for berry weight, size, length and diameter as compared with control. 
TABLE 2. Effect of clusters thinning, leaf basal removal and girdling on physical properties of King Ruby grapevines berries in 2014 and 2015 seasons.

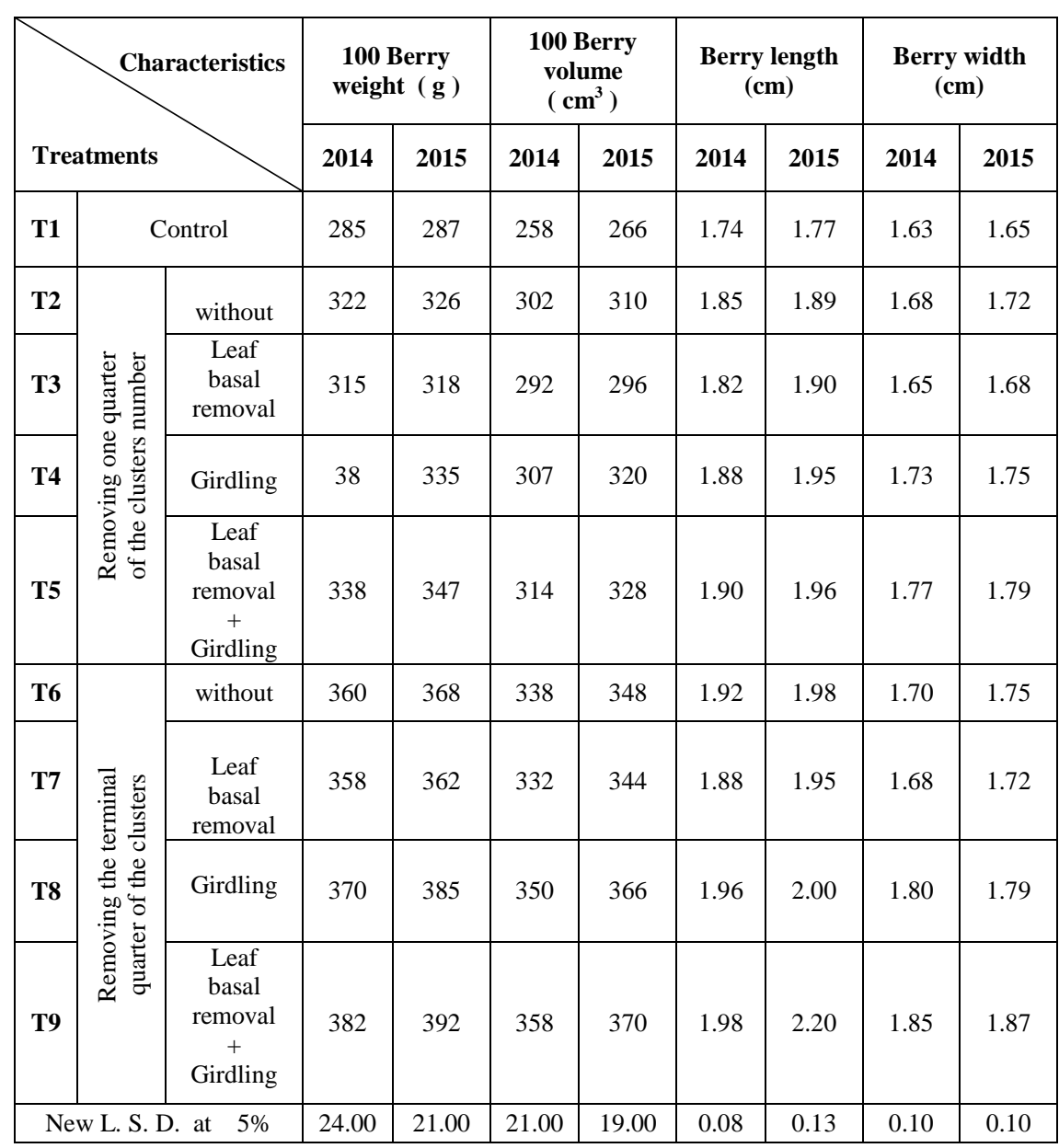

\section{Chemical properties of berries}

Data in Table 3 and 4 revealed that all thinning treatments used either removing one quarter of the clusters number or removing the terminal quarter of the cluster alone or in combination with leaf basal removal or girdling and leaf basal removal in combination with girdling significantly increased SSC\%, SSC/acid ratio, total sugar and total anthocyanin in berry skin and gave the least acidity of berry juice as compared to control during the two seasons of study. Where girdling (T4) and leaf basal removal in combination with girdling (T5) treatments under removing one quarter of the clusters number as well as girdling (T8) and leaf basal removal in combination with girdling (T9) treatments under removing the terminal quarter of the cluster gave the highest values in SSC\%, $\mathrm{SSC} /$ acid ratio, total sugar and least acidity of the juice. While leaf basal removal Egypt. J. Hort. Vol. 43, No.1 (2016) 
(T3) and leaf basal removal in combination with girdling (T5) treatments under removing one quarter of the clusters number as well as leaf basal removal (T7) and leaf basal removal in combination with girdling (9) treatments under the terminal quarter of the cluster gave the highest values in total anthocyanin in berry skin as compared to other treatments in both seasons of study.

TABLE 3. Effect of clusters thinning, leaf basal removal and girdling on SSC \%, acidity \% and SSC/ acid ratio of King Ruby grapevines berries in $\mathbf{2 0 1 4}$ and 2015 seasons.

\begin{tabular}{|c|c|c|c|c|c|c|c|c|}
\hline \multirow{2}{*}{\multicolumn{3}{|c|}{ Treatments }} & \multicolumn{2}{|c|}{$\operatorname{SSC}(\%)$} & \multicolumn{2}{|c|}{ Acidity (\%) } & \multicolumn{2}{|c|}{ SSC/Acid ratio } \\
\hline & & & 2014 & 2015 & 2014 & 2015 & 2014 & 2015 \\
\hline $\mathrm{T} 1$ & \multicolumn{2}{|c|}{ Control } & 16.40 & 16.06 & 0.505 & 0.518 & 32.48 & 31.00 \\
\hline $\mathrm{T} 2$ & \multirow{4}{*}{ 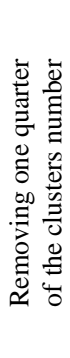 } & without & 17.00 & 16.86 & 0.476 & 0.485 & 35.71 & 34.76 \\
\hline $\mathrm{T} 3$ & & $\begin{array}{c}\text { Leaf basal } \\
\text { removal }\end{array}$ & 17.26 & 17.40 & 0.468 & 0.458 & 36.88 & 37.99 \\
\hline $\mathrm{T} 4$ & & Girdling & 18.20 & 18.26 & 0.430 & 0.425 & 42.33 & 42.96 \\
\hline T5 & & $\begin{array}{c}\text { Leaf basal } \\
\text { removal } \\
+ \\
\text { Girdling }\end{array}$ & 18.53 & 18.66 & 0.420 & 0.410 & 44.12 & 45.51 \\
\hline T6 & \multirow{4}{*}{ 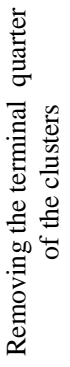 } & without & 17.40 & 17.53 & 0.468 & 0.462 & 37.18 & 37.94 \\
\hline $\mathrm{T} 7$ & & $\begin{array}{c}\text { Leaf basal } \\
\text { removal }\end{array}$ & 17.86 & 18.00 & 0.452 & 0.445 & 39.51 & 40.45 \\
\hline $\mathrm{T} 8$ & & Girdling & 18.60 & 18.53 & 0.415 & 0.419 & 44.81 & 44.22 \\
\hline T9 & & $\begin{array}{c}\text { Leaf basal } \\
\text { removal } \\
+ \\
\text { Girdling }\end{array}$ & 18.86 & 19.00 & 0.407 & 0.400 & 46.34 & 47.50 \\
\hline \multicolumn{3}{|c|}{ New L. S. D. at $5 \%$} & 0.56 & 0.66 & 0.02 & 0.02 & 3.21 & 3.52 \\
\hline
\end{tabular}

The obtained results are in agreement with the findings of Omran et al. (2004), Abd El-Wahab (2006), Aisha et al. (2006), El-Hussanny (2009), Abd El-Fattah et al. (2009), Abd El-Razek et al. (2010) and Fazekas et al. (2012) they all reported that manual thinning was found to increase SSC \%, SSC/acid ratio, total sugar and total anthocyanin in berry skin and reduce total acidity in berry juice.

Also, Abd El-Razek et al. (2010) found that leaf basal removal and leaf basal removal in combination with fruit thinning significantly increased SSC \%, $\mathrm{SSC} /$ acid ratio, total sugars and total anthocyanin in berry skin and decreased the total acidity of Crimson Seedless grapevines. In additions, Abd El-Wahab 
(2006), El-Hussanny (2009), Abu Zahra (2010), Abd El-Razek et al. (2010), Ratther et al. (2011) and Abu Zahra \& Salmeh (2012) they found that trunk girdling or cane girdling increased SSC \%, SSC/acid ratio, total sugars and improved berry colorations while decreased acidity of berry juice.

Concerning the effect of manual thinning, leaf basal removal and girdling treatments on total carbohydrates in canes the data in Table 4 showed that all thinning treatments used either removing one quarter of the clusters number or removing the terminal quarter of the cluster alone or with girdling treatments gave significant increased total carbohydrates in canes as compared to control. Where girdling treatment (T4) and leaf basal removal in combination with girdling treatment (T5) under removing one quarter of the clusters number as wells as girdling treatment (T8) and leaf basal removal in combination with girdling treatment (T9) under removing the terminal quarter of the cluster gave the highest values in this respect as compared with other treatments during the two seasons of study.

TABLE 4. Effect of clusters thinning, leaf basal removal and girdling on total sugars, total anthocyanin in berries and total carbohydrates in cans of King Ruby grapevines in 2014 and 2015 seasons.

\begin{tabular}{|c|c|c|c|c|c|c|c|c|}
\hline \multirow{2}{*}{\multicolumn{2}{|c|}{ Treatments }} & \multirow{2}{*}{ aracteristics } & \multicolumn{2}{|c|}{$\begin{array}{c}\text { Total Sugars } \\
(\%)\end{array}$} & \multicolumn{2}{|c|}{$\begin{array}{c}\text { Total } \\
\text { Anthocyanin } \\
\text { (mg/100g F.W.) }\end{array}$} & \multicolumn{2}{|c|}{$\begin{array}{c}\text { Total } \\
\text { Carbohydrates } \\
(\%) \\
\end{array}$} \\
\hline & & & 2014 & 2015 & 2014 & 2015 & 2014 & 2015 \\
\hline $\mathrm{T} 1$ & \multicolumn{2}{|c|}{ Control } & 13.49 & 13.10 & 28.09 & 29.8 & 21.63 & 22.50 \\
\hline $\mathrm{T} 2$ & \multirow{4}{*}{ 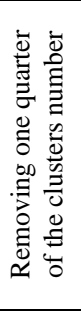 } & without & 14.11 & 13.94 & 33.60 & 34.43 & 23.84 & 24.58 \\
\hline $\mathrm{T} 3$ & & $\begin{array}{l}\text { Leaf basal } \\
\text { removal }\end{array}$ & 14.23 & 14.27 & 36.06 & 37.13 & 22.96 & 23.47 \\
\hline $\mathrm{T} 4$ & & Girdling & 15.47 & 15.65 & 35.85 & 36.26 & 25.78 & 26.53 \\
\hline T5 & & $\begin{array}{c}\text { Leaf basal } \\
\text { removal } \\
+ \\
\text { Girdling } \\
\end{array}$ & 15.82 & 15.94 & 38.09 & 39.10 & 26.25 & 27.13 \\
\hline $\mathrm{T} 6$ & \multirow{4}{*}{ 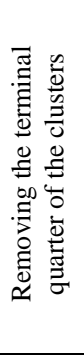 } & without & 14.62 & 14.69 & 34.63 & 35.66 & 23.44 & 23.95 \\
\hline $\mathrm{T} 7$ & & $\begin{array}{l}\text { Leaf basal } \\
\text { removal }\end{array}$ & 14.96 & 15.14 & 38.13 & 38.10 & 22.58 & 22.62 \\
\hline $\mathrm{T} 8$ & & Girdling & 16.05 & 15.82 & 37.68 & 37.80 & 24.47 & 25.37 \\
\hline T9 & & $\begin{array}{c}\text { Leaf basal } \\
\text { removal } \\
+ \\
\text { Girdling }\end{array}$ & 16.25 & 16.37 & 39.46 & 40.68 & 25.22 & 26.13 \\
\hline \multicolumn{3}{|c|}{ New L. S. D. at $5 \%$} & 0.60 & 0.56 & 0.42 & 0.36 & 1.18 & 0.85 \\
\hline
\end{tabular}

Egypt. J. Hort. Vol. 43, No.1 (2016) 
The data are in agreement with Abd El-Wahab (2006) who reported that girdling trunk at version stage alone or in combination with all berry thinning treatments increased total carbohydrates in canes as compared to control in the two seasons of study.

The improvement of yield, physical and chemical characteristics of cluster and berries as a result of using manual thinning, leaf basal removal and girdling treatments may be due to manual thinning which is a method of the yield regulation. With the removal one part of the clusters, the yield per leaf area will be lower hereby the yield and quality will be improved. Fazekas et al. (2012).

Regarding the leaf basal removal treatment, leaf basal removal is important in canopy management. Sunlight-exposed fruits contain more sugar and less acid than non-exposed ones Koblet et al. (1984). Removing basal leaves slightly changed temperature atmospheric humidity, wind speed and leaf wetness around grape clusters English et al. (1990). Sunlight-exposed fruits are generally greater in total soluble solids and anthocyanin and lower in titratable acidity compared to non-exposed fruits or canopy shaded Ferree et al. (2004), Kliewer \& Dokoozlian (2005), Santesteban \& Royo (2006) and Prajitna et al. (2007).

Concerning the girdling treatment, girdling grapevines increases carbohydrate concentration above girdle which the transport sugars from leaves to the root system is effectively blocked and resulted in large berries intended for table use or to enhance fruit quality by enhancing berry coloration or accumulation of sugars Williams \& Ayars (2005) and Abu Zahra \& Salmeh (2012).

\section{Conclusion}

According to the results obtained from this present study, it can be concluded that technical operations such as manual thinning, leaf basal removal and girdling considered to be very important in 'King Ruby grapevines' vineyards for improving fruit quality. Where treatment of removing the terminal quarter of the clusters in combination with leaf basal removal after fruit set and girdling at veraison stage gave the best values in yield, berry weight, berry size, SSC\%, total sugar and total anthocyanin in berry skin as well as decreased the acidity in berries and decreases the percentage of shot berries /cluster. Moreover, increased total carbohydrates in canes.

\section{References}

A.O.A.C. (1980) "Association of Official Analytical Chemists". $14^{\text {th }}$ ed., published by A.O.A.C., Washington D.C., USA.

Abd El-Fattah, M.E., Amen, K.A., Alaa, A.B. and Eman A.A. Abo Zeed (2009) Effect of berry thinning, CPPU spraying and pinching on cluster and berry quality of two grapevine cultivars. Assiut J. Agric. Sci., 40 (4) 92-107.

Abd El-Ghany, A.A., Omran, Y.A.M. and Abd El-Galil, H.A. (2005) Effect of summer pruning on Thompson Seedless grapevines productivity. Assiut J. Agric. Sci., 36 (5) $167-180$. 
Abd El-Razek, E., Treutter, D., Saleh, M.M.S., El-Shammaa, M., Amira, A. Fouad, Abd El-Hamid, N. and Abou-Rawash, M. (2010) Effect of defoliation and fruit thinning on fruit quality of 'Crimson Seedless' grape. Res. J. Agri. Biolo. Sci., 6 (3), 289-295.

Abd El-Wahab, M.A. (2006) An attempt towards improving bunch quality through berry thinning and trunk girdling treatments in Black Monukka grape. J. Agric. Sci Mansoura Univ., 31 (10) 6577-6593.

Abu-Zahra, T.R. (2010) Berry size of Thompson Seedless as influenced by the application of Gibberellic acid and cane girdling. Pak. J. Bot., 42 (3), 1755-1760.

Abu-Zahra, T.R. and Salameh, N.M. (2012) Influence of Gibberellic acid and cane girdling on berry size of black magic grape cultivar Middle-East. J. Sci. Res., 11 (6), 718-722.

Aisha S.A. Gaser, Hanaa, A. EL-Helw and Abd EL-Wahab, M.A. (2006) Timing of cluster thinning as a method for crop adjusting and its impact on growth, yield and fruit quality of Ruby Seedless grapevines. J. Agric. Sci. Mansoura Univ., 31 (10), $6561-6575$

El-Hussanny, T.A.M. (2009) Studies on improving yield and berries quality of Red Roumy grapevine under different pruning severity. Ph.D. Thesis, Fac. of Agric., Mansoura Univ. Egypt.

English, J.T., Bledose, A.M., Marois, J.J. and Kliewer, W.M. (1990) Influence of grapevine canopy management on evaporative potential in the fruit zone. Amer. J. Enol. Viticult., 41, 137-141.

Fawzi, M.I.F. and Eman A.A. Abd El-Moniem (2003) Effect of girdling alone or combined with flower cluster thinning and ethephon application on fruit set, yield and quality of Black Monukka grapes. Arab Univ., J. Sci., Ain Shams Univ., 11 (2), 733-750.

Fazekas, I., Göblyös, J., Bisztray, Gy.D. and Zanathy, G. (2012) The effect of cluster thinning, cluster tipping, cluster shredding and defoliation at the flowering on the vegetative and generative vine performance from Kékfrankos Cv. Inter. J. Hort. Sci., 18 (1), 63-68.

Ferree, D.C., Scurlock, D.M., Steiner, T. and Gallander, J. (2004) 'Chambourcin' grapevine response to crop level and canopy shade at bloom. J. Amer. Pomology Soc., 58 (3), 135-141.

Hamza, D. M. (2013) Physical studies on King Ruby Seedless grapevines. Ph. D. Thesis, Fac. Agric., Mansoura Univ. Egypt.

Hedge, I.E. and Hofreiter, B.T. (1962) "Carbohydrate Chemistry", $7^{\text {th }}$ ed., Whistler R.L. and Be Miller, J.N. Academic Press, New York.

Husia, C.L., Luh B.S. and Chichester, C.D. (1965) Anthocyanin in free stone peach. $J$. Food Sci., 30, 5-12.

Kamiloğlu, Ö. (2011) Influence of some cultural practices on yield, fruit quality and individual anthocyanin of table grape cv. 'Horozkarasi'. J. of Animal \& Plant Sci., 21 (2), 240-245.

Egypt. J. Hort. Vol. 43, No.1 (2016) 
Kliewer, W.M. and Dokoozlian, N.K. (2005) Leaf area /crop weight ratio of grapevines influence on fruit composition and wine quality. Proceedings of the ASEV $50^{\text {th }}$ Anniversary Annual Meeting. Amer. J. Enol. Vitic., 56, 170-181.

Koblet, W. (1984) Influence of light and temperature on vine performance in cool climates and application to vineyard management. Proc. Inter. Symposium on Cool Climate Viticulture and Enology, Eugene, USA. Oregon State Univ., 139-157.

Ministry of Agriculture (2013) Agriculture Economics vol. 6. June.

Omar, A.H. and Girgis, V.H. (2005) Some treatments affecting fruit quality of Crimson Seedless grapevine. J. Agric. Sci Mansoura Univ., 30 (8) 4665-4673.

Omran,Y.A.M., Abd El-Ghany, A.A. and Hanaa A. El-Helw (2004) Improvement of cluster shape and fruit quality of Red Roumy grapevines. Assuit J. Agric. Sci. 35 (2), 183-194.

Prajitna, A., Dami I.E., Steiner, T.E., Ferree D.C., Scheerens, J.C. and Schwartz S.J. (2007) Influence of cluster thinning on phenolic composition, resveratrol and antioxidant capacity in Chambourcin wine. Amer. J. Enol. Vitic., 58, 346 - 350.

Rather, J.A., Wani, S.H., Haribhushan, A. and Bhat, Z.A. (2011) Influence of girdling, thinning and $\mathrm{GA}_{3}$ on fruit quality and shelf life of grape (vitis vinifera) cv. Perlette. Elixir Agriculture, 41, 5731-5735.

Reynolds, A.G., Roller J.N., Forgione, A. and Savigny C.De. (2006) Gibberellic Acid and basal leaf removal: Implications for fruit maturity, vestigial seed development and sensory attributes of Sovereign Coronation table grapes. Amer. J. Enol. Vitic., 57, 41-53.

Sadasivam, S. and Manickam, A. (1996) "Biochemical Methods", $2^{\text {nd }}$ ed., New Age International, India.

Santesteban, L.G. and Royo, J.B. (2006) Water status, leaf area and fruit load Influence on berry weight and sugar accumulation of cv. 'Tempranillo' under Semi arid conditions. Sci. Hort., 109, 60-65.

Snedecor, G.W. and Cochran, W.G. (1980) "Statistical Methods", $7^{\text {th }}$ ed., The Iowa State Univ. Press, U.S.A., 593 p.

Williams, L.E. and Ayars, J.E. (2005) Water use of Thompson Seedless grapevines as affected by application of Gibberellic acid (GA) and trunk girdling - practices to increase berry size. Agriculture and Forest Meteorology, 129, 85-94.

Winkler, A.J., Cook, J.A., Kliewer, W.M. and Lider, L.A. (1974) General Viticulture. Univ. of Calif. Press. Barkely and loss Angeles. 


\section{استخدام بعض العمليات الفنية لتحسين جودة العنب الكنج روبى}

بسام العيد عبد المقصود بلال ، مسعد عوض القتاوى و محمد على مجاورعبادة

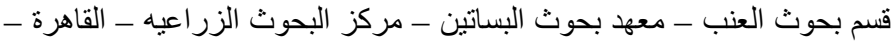

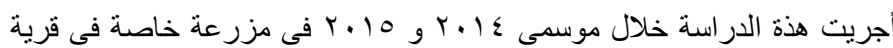

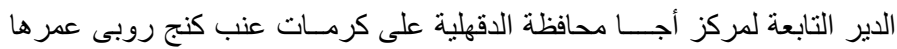

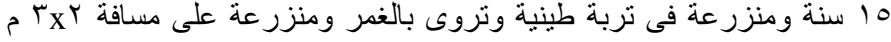
ومرباه بالطريقة الكردونية وتحت نظام تدعيم حرف T المذدورج.

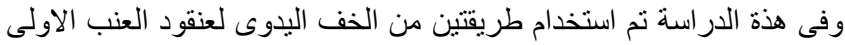

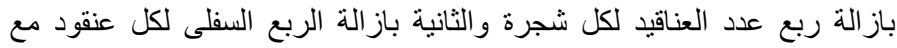

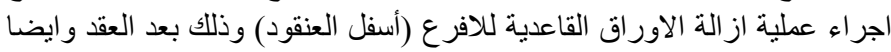

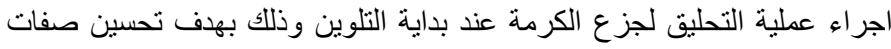

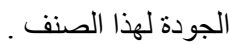

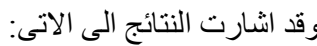

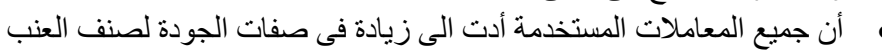

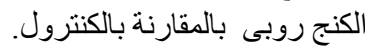

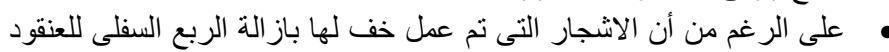

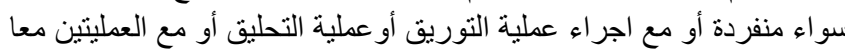

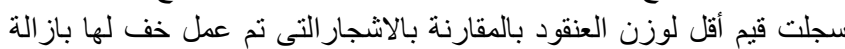

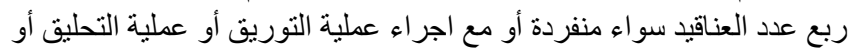

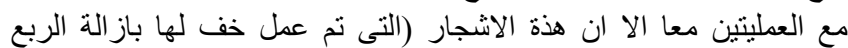

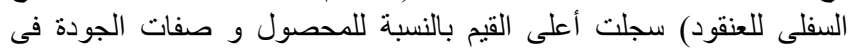

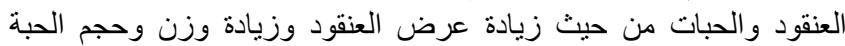
وطول وعرض الحبة وزيادة نسبة المو واد الصلبة الذائبة و والسكريات الكلية ولئية

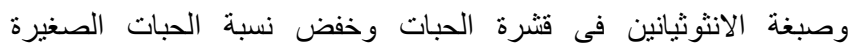
(الحصرم) فى العنقود بالاضافة الى زيادة نسبة الكربو هيدرات الكلية فى الحئ

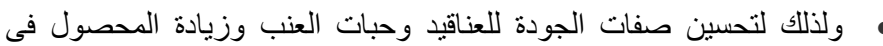

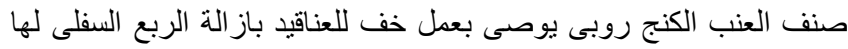

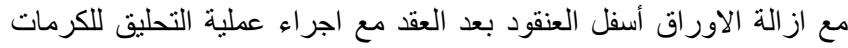

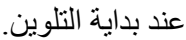

